\title{
Finger millet as a carbon source for biofloc, improved growth performance of Pangasianodon hypophthalmus (Sauvage, 1878) fingerlings
}

\author{
P. NAGESWARI ${ }^{1}$, A. K. VERMA ${ }^{1 *}$, SUBODH GUPTA $^{1}$ AND A. JEYAKUMARI ${ }^{2}$ \\ ${ }^{1}$ ICAR-Central Institute of Fisheries Education, Andheri (W), Mumbai - 400 061, Maharashtra, India \\ ${ }^{2}$ ICAR-Central Institute of Fisheries Technology, Navi Mumbai - 400 703, Maharashtra, India \\ e-mail: akverma@cife.edu.in
}

\begin{abstract}
A 90-days experiment was conducted to investigate the effects of biofloc produced with different carbon sources on growth performances, survival and body indices of Pangasianodon hypophthalmus fingerlings (average body weight: $6.4 \pm 0.05 \mathrm{~g}$ ). The different carbon sources used in the experiment employing biofloc technology (BFT) were BFT-T (tapioca), BFT-S (sorghum), BFT-PM (pearl millet), BFT-FM (finger millet) and clear water with no addition of carbon source was treated as control. At the end of the experiment, significantly $(p<0.05)$ higher weight gain $(24.34 \pm 0.50 \mathrm{~g})$, Specific growth rate, SGR (1.37 $\pm 0.02 \%$ day $\left.^{-1}\right)$; Feed efficiency ratio, FER (0.47 \pm 0.01$)$; Protein efficiency ratio, PER (1.47 \pm 0.03$)$ and lower Feed conversion ratio, FCR $(2.12 \pm 0.03)$ were witnessed in the group where finger millet was used as a carbon source (BFT-FM) and significantly lower responses were noticed in the control $(\mathrm{CW})$. Results showed that there were no significant differences $(\mathrm{p}>0.05)$ in hepatosomatic index and viscerosomatic index of fish between the different experimental groups. During the termination of the experiment, no mortality was seen among the different experimental groups. Based on the results acquired from this study, finger millet could be used as an ideal carbon source for biofloc to augment the growth and productivity of $P$. hypophthalmus under farming.
\end{abstract}

Keywords: Biofloc, Carbon source, Finger millet, Fish culture, Sutchi catfish

\section{Introduction}

Fisheries and aquaculture are the fastest emerging food producing sectors providing extensive contributions to food, nutrition, income and livelihoods for millions of people (FAO, 2016). Contemporary catfish farming sector in the country is operated at marginal profit levels, for which long term feasibility would be encouraged by the development of new protocols for the grow-out farming systems (Phan et al., 2009; De Silva and Phuong, 2011). The striped catfish Pangasianodon hypophthalmus (Sauvage, 1878), also known as iridescent shark and sutchi catfish (Family Pangasiidae) is considered as a unique candidate species for aquaculture in the country attributable to its fast growth rate, in conjunction with high demand and economic value in domestic and international markets (Singh and Lakra, 2012).

For decades, one of the most popular research areas in aquaculture is the study on effects of biofloc technology (BFT) on growth and survival performances of farmed fish and shellfish. Developments have revealed that this technology ensure prospective to boost the biomass of the cultured animals (Avnimelech, 2012; Bossier and Ekasari, 2017). BFT also improves the growth performance through additional microbial floc and stimulates digestive enzyme activities and immune responses in various fish species (Widanarni and Puspita, 2012; Ekasari et al., 2015; Ahamed et al., 2016). BFT has been widely adopted in the field of aquaculture and has received substantial interest among the fish farmers of the country (Daniel and Nageswari, 2017). It has been established that biofloc turns toxic nitrogen metabolites (such as $\mathrm{NH}_{3}$ and $\mathrm{NO}_{2}$ ) available in the water column into microbial floc which would be available as feed for aquatic animals (Avnimelech, 2007; De Schryver et al., 2008). BFT works on the principle of stimulating the process of carbon to nitrogen ratios through the addition of an exogenous carbon source that subsequently stimulates natural heterotrophic bacterial growth in the system (Hargreaves, 2006; De Schryver et al., 2008).

Previous research showed that the addition of organic carbon sources, such as sugar cane molasses and commercial wheat flour can be used to prevent the accrual of ammonium nitrogen and nitrite nitrogen in BFT systems (Samocha et al., 2007; Haridas et al., 2017). A number of authors have recognised that different organic carbon sources can possibly affect the composition of biofloc (Hollender et al., 2002; Oehmen et al., 2004). As has been previously reported in the literature that the choice of carbon sources in a biofloc based system could substantially affect the biofloc productivity, nutritive value and water quality as well as growth performance 
of the fish. In the literature, there are many studies in biofloc with respect to different carbon sources and their effect on aquatic animals (Ahmad et al., 2017). As far as we know, no previous research has been carried out in P. hypophthalmus using biofloc with different carbon sources. Therefore the present study was undertaken to evaluate the effects of various carbon sources on the growth performance of $P$. hypophthalmus fingerlings raised under biofloc system.

\section{Materials and methods}

\section{Preparation of biofloc inoculum}

In the present study, biofloc inoculum was developed with four different carbon sources such as tapioca, sorghum, pearl millet and finger millet employing the standard protocol described by Avnimelech (1999). After biofloc inoculum development, the inoculum water was transferred into different treatment tanks. The biofloc volumes of the experimental tanks were regularly checked during the study with the help of Imhoff cone.

\section{Experimental design and set up}

A 90 days experiment was conducted in the wet laboratory at ICAR-Central Institute of Fisheries Education (ICAR-CIFE), Mumbai following completely randomised design. Fingerlings of $P$. hypophthalmus with an average weight of $6.4 \pm 0.05 \mathrm{~g}$ were initially stocked at a density of 20 fish per 1001 in the rectangular experimental tanks (fibre glass) $(72 \times 56 \times 40 \mathrm{~cm})$. Four different carbon sources viz. tapioca, sorghum, pearl millet and finger millet flour were selected to identify the potential carbon source for the production of $P$. hypophthalmus fingerlings in biofloc system. The carbon sources were ground to fine flour before using for biofloc production. The biochemical composition of the carbon sources were analysed (Table 1). The set-up of the experiment contained four treatments with different carbon sources for the development of biofloc viz. BFT-Tapioca (BFT-T), BFTSorghum (BFT-S), BFT-Pearl millet (BFT-PM), BFTFinger millet (BFT-FM) and the control (clear water). The tanks were continuously aerated using air stones connected to an air pump. To induce heterotrophic medium of biofloc, carbon sources were added 15 times of the total ammonia nitrogen (TAN) concentration to maintain a carbon:nitrogen ratio $(\mathrm{C}: \mathrm{N})$ of $15: 1$ as suggested by Crab et al. (2012). During the course of the experiment, all the experimental fishes were fed with commercial pellet feed having $32 \%$ crude protein.

\section{Evaluation of growth performances and survival}

Growth performance of $P$. hypophthalmus in different experimental groups were assessed on termination of the experiment. Before sampling, fishes were starved for $24 \mathrm{~h}$ and weighed in an electronic balance with an accuracy of $0.01 \mathrm{~g}$. Body indices of fish were calculated at the end of the experiment by sacrificing the animals.

Growth parameters and survival of the animals were calculated using the following equations:

Weight gain in $\mathrm{g}(\mathrm{WG})=$ Final weight - Initial weight ....(1)

Specific growth rate per day $(\mathrm{SGR})=[(\mathrm{Ln}$ Final weight $(\mathrm{g})-$

Ln Initial weight $(\mathrm{g}) /$ Time (days) $] \times 100 \ldots \ldots \ldots \ldots . . . \cdots \cdots \cdots . . . . . . .(2)$

Feed conversion ratio $(\mathrm{FCR})=$ Feed given $($ Dry weight $) /$

Body weight gain (Wet weight)

Feed efficiency ratio $($ FER $)=$ Body weight gain $($ Wet

weight) / Feed given (Dry weight)

Protein efficiency ratio (PER) $=$ Body weight gain (Wet

weight) / Crude protein in feed)

Hepatosomatic index (HSI) $(\%)=[$ Wet weight of liver $(\mathrm{g}) /$

Wet weight of fish $(\mathrm{g})] \times 100$

Viscerosomatic index (VSI) $(\%)=[$ Wet weight of viscera $(\mathrm{g}) /$ Wet weight of fish $(\mathrm{g})] \times 100$

Survival $(\%)=($ Total number of fish harvested $/$ Total

number of fish stocked) $\mathrm{x} 100$

Biofloc volume (BFV)

Biofloc volume (BFV) was measured using Imhoff Cone (Merck Specialties, Mumbai, India). by allowing the biofloc to settle down for 15 min without disturbance. The concentration of settled flocs were expressed in $\mathrm{ml} \mathrm{l}^{-1}$.

\section{Statistical analysis}

The data were statistically analysed using the statistical package SPSS ver. 20.00 (SPSS, Chicago, USA). Duncan's multiple range tests were used for the comparison of mean among the different treatments (Duncan, 1955). All data presented in the tables are Mean $\pm \mathrm{SE}$ error and statistical significance for all statistical tests was set at $\mathrm{p}<0.05$.

\section{Results and discussion}

The growth performances and survival of $P$. hypophthalmus reared in the control and four biofloc

Table 1. Biochemical composition (\% dry matter basis) of four different carbon sources

\begin{tabular}{lllll}
\hline Composition (\%) & Tapioca & Sorghum & Pearl millet & Finger millet \\
\hline Crude protein & 10.46 & 10.6 & 11.0 & 10.5 \\
Crude fat & 1.19 & 1.0 & 1.5 & 1.8 \\
Nitrogen-free extract & 54.5 & 59.4 & 69.4 & 63.4 \\
Crude fibre & 4.16 & 2.0 & 1.0 & 1.5 \\
Ash & 3.10 & 2.68 & 5.14 & 5.13 \\
\hline
\end{tabular}


treatments after the 90 days of experiment are given in Table 2.

\section{Weight gain and specific growth rate}

Weight gain (WG) and specific growth rate (SGR) of P. hypophthalmus were found to be significantly $(\mathrm{p}<0.05)$ different among the treatment groups and control. Within the treatments, the highest WG and SGR were observed in the group reared under the biofloc produced by finger millet as a carbon source (BFT-FM) followed by pearl millet (BFT-PM), sorghum (BFT-S), tapioca (BFT-T) and lowest response was seen in the control $(\mathrm{CW})$. Previous studies indicated that the effect of biofloc on the growth performances of aquatic animals depends on the carbon source (Zhao et al., 2012; Panigrahi et al., 2019). The results thus obtained are compatible with the previous work as it found varying performances in the growth of $P$. hypophthalmus in response to different carbon sources used. The highest WG and SGR observed in the animals reared under the biofloc using finger millet as a carbon source could be attributed to effective utilisation of the biofloc produced by finger millet by sutchi catfish. The results of the present study are in accordance with previous findings in Labeo rohita (Kamilya et al., 2017), P. hypophthalmus (Meritha et al., 2018) and Clarias gariepinus (Soedibya et al., 2018) cultured in biofloc system with different carbon sources.

\section{Feed conversion ratio}

The lowest and the best $(\mathrm{p}<0.05)$ FCR was recorded in the treatment group with finger millet as a carbon source (BFT-FM) followed by pearl millet (BFT-PM), sorghum (BFT-S), tapioca (BFT-T) and the highest and poor FCR was found in the control (clear water) among all the experimental groups. FCR is one of the important parameters which determine the profitability of the aquaculture venture as it measures the weight of the fish produced per kilogram of the feed given. It is commonly perceived that the lower the FCR, the higher the weight gain obtained from the feed. We speculate that the lower FCR distinguished in the treatment group with finger millet as carbon source could be due to the fact that the bioavailability of biofloc produced by this carbon source would be higher when compared to other carbon sources. Similar results were recorded by earlier researchers in fish when varying carbon sources were used in biofloc experiment (Bakar et al., 2015; Long et al., 2015; Bakhshi et al., 2018).

\section{Protein efficiency ratio}

The mean PER value was significantly $(p<0.05)$ higher in the different treatment groups as compared to the control (clear water). Among the treatments, the highest PER value was obtained in finger millet (BFT-FM) followed by pearl millet (BFT-PM), sorghum (BFT-S), tapioca (BFT-T) and the least PER value was found in the control (clear water) group. Conventionally, PER is employed as a measure to evaluate how efficiently fish can utilise the protein available in the feed. In the present study, the highest PER value obtained with finger millet as carbon source could be attributed to the fact that pangasius could effectively convert microbial protein into body mass. Presumably, finger millet could be used as a viable carbon source to enhance microbial protein in the biofloc. A comparable conclusion was also reached by earlier researchers in response to research work with different carbon sources for biofloc (Azim and Little, 2008; Ahmad et al., 2016; Rajkumar et al., 2016).

\section{Feed efficiency ratio}

The FER value of different treatment groups observed in the present study was similar to the results of PER. FER value describes the efficiency of feed intake on growth performances of the animals. The higher FER value obtained in pangasius in response to finger millet carbon source may be due to the fact that this carbon source

Table 2. Growth performance and survival of P. hypophthalmus reared in the control and different biofloc treatment groups after 90 days experimental period

\begin{tabular}{llllll}
\hline Parameters & C & BFT-T & BFT-S & BFT-PM & BFT-FM \\
\hline WG $(g)$ & $16.56^{\mathrm{a}} \pm 0.61$ & $20.67^{\mathrm{b}} \pm 0.20$ & $21.34^{\mathrm{bc}} \pm 0.50$ & $21.92^{\mathrm{c}} \pm 0.21$ & $24.34^{\mathrm{d}} \pm 0.50$ \\
SGR $\left(\%\right.$ day $\left.^{-1}\right)$ & $1.08^{\mathrm{a}} \pm 0.03$ & $1.23^{\mathrm{b}} \pm 0.01$ & $1.26^{\mathrm{bc}} \pm 0.02$ & $1.28^{\mathrm{c}} \pm 0.01$ & $1.37^{\mathrm{d}} \pm 0.02$ \\
FCR & $2.53^{\mathrm{d}} \pm 0.04$ & $2.44^{\mathrm{cd}} \pm 0.03$ & $2.37^{\mathrm{bc}} \pm 0.05$ & $2.29^{\mathrm{b}} \pm 0.02$ & $2.12^{\mathrm{a}} \pm 0.03$ \\
PER & $1.23^{\mathrm{a}} \pm 0.03$ & $1.27^{\mathrm{ab}} \pm 0.02$ & $1.31^{\mathrm{bc}} \pm 0.03$ & $1.36^{\mathrm{c}} \pm 0.01$ & $1.47^{\mathrm{d}} \pm 0.03$ \\
FER & $0.39^{\mathrm{a}} \pm 0.01$ & $0.40^{\mathrm{ab}} \pm 0.01$ & $0.42^{\mathrm{bc}} \pm 0.01$ & $0.43^{\mathrm{c}} \pm 0.00$ & $0.47^{\mathrm{d}} \pm 0.01$ \\
HSI (\%) & $1.78 \pm 0.03$ & $1.77 \pm 0.01$ & $1.69 \pm 0.02$ & $1.69 \pm 0.03$ & $1.63 \pm 0.02$ \\
VSI (\%) & $2.82 \pm 0.60$ & $2.71 \pm 0.41$ & $2.76 \pm 0.55$ & $2.84 \pm 0.14$ & $2.65 \pm 0.78$ \\
Survival (\%) & $100 \pm 0.00$ & $100 \pm 0.00$ & $100 \pm 0.00$ & $100 \pm 0.00$ & $100 \pm 0.00$ \\
BFV (ml l-1) & $1.50^{\mathrm{a}} \pm 0.80$ & $19.61^{\mathrm{b}} \pm 0.28$ & $20.52^{\mathrm{b}} \pm 4.50$ & $21.72^{\mathrm{b}} \pm 2.78$ & $25.50^{\mathrm{c}} \pm 3.42$
\end{tabular}

WG - Weight gain; SGR - Specific growth rate; FCR - Feed conversion ratio; FER - Feed efficiency ratio; PER - Protein efficiency ratio; BFV - Biofloc volume

BFT-T: Tapioca; BFT-S: Sorghum; BFT-PM: Pearl millet; BFT-FM: Finger millet; C: Clear water

Values are expressed as Mean \pm SE. Values in the same row with different superscripts differ significantly $(\mathrm{p}<0.05)$ for each parameter 
could provoke the feed intake of the animals. The higher feeding responses to this condition may be substantiated by presence of some natural feeding stimulants in the biofloc (Ju et al., 2008) which are supported by previous studies in fish with response to different carbon sources (Avnimelech 1999; Widanarni and Puspita, 2012; Ezhilarasi et al., 2019).

\section{Body indices (HSI and VSI)}

The hepatosomatic index (HSI) and viscerosomatic index (VSI) of fish among the different experimental groups are shown in Table 2. It is generally believed that HSI and VSI are the two important parameters to assess the health status of aquatic animals. However, different carbon sources for biofloc did not significantly $(p>0.05)$ affect the HSI and VSI values of the experimental fishes in this study. Previous researchers also found similar results in common carp (Cyprinus carpio L.) fingerlings when exposed to different carbon source based biofloc grow-out culture. The results of the study are also consistent with the findings of Dauda et al. (2017) in C. gariepinus reared under different carbon source based biofloc systems. This may be possible because biofloc might have potential to provoke the growth, but no influence on body indices of fish.

\section{Survival}

During the course of the study, no mortality of $P$. hypophthalmus was observed in the control as well as different treatment groups and the $100 \%$ survival rate achieved in all the experimental groups could be attributed to the maintenance of favourable environmental conditions throughout the experiment. The findings are directly in line with previous authors who also noticed $100 \%$ survival of fish when raised under biofloc and clear water conditions (Mahanand et al., 2013; Najdegerami et al., 2015; Deng et al., 2018).

\section{Biofloc volume (BFV)}

Biofloc volume varied significantly $(\mathrm{p}<0.05)$ among the treatment groups during the present study. Higher mean floc volume was observed in BFT-FM $\left(25.50 \pm 3.42 \mathrm{ml} \mathrm{l}^{-1}\right)$ which differed significantly from control and other biofloc treatment groups $(\mathrm{p}<0.05)$. BFT-PM treatment groups recorded mean floc volume of $21.72 \pm 2.78 \mathrm{ml} \mathrm{l}^{-1}$ followed by BFT-S $\left(20.52 \pm 4.50 \mathrm{ml} \mathrm{l}^{-1}\right)$, BFT-T $\left(19.61 \pm 0.28 \mathrm{ml} \mathrm{l}^{-1}\right)$ and control $\left(1.50 \pm 0.80 \mathrm{ml} \mathrm{l}^{-1}\right)$. The results of this study concurred with that of the previous authors who reported supplementation of different carbon sources at varied levels could affect the biofoc volume, microbial and nutrient composition (Wang et al., 2015; Zhao et al., 2016; Dauda et al., 2017; Ahmad et al., 2019; Panigrahi et al., 2019). Furthermore, finger millet organic carbon source has the potential for higher biofloc production as well as to improve growth performance of pangasius fingerling culture in zero water exchange system.

Based on the growth performances of sutchi catfish in this study, the authors conclude that finger millet could be used as an ideal carbon source for biofloc production in sutchi catfish farming. To our knowledge, this is the first report to show the promising effect of finger millet as a carbon source for biofloc in sutchi catfish farming. Looking forward, further attempts on other cultivable fishes in the same research area could confirm this finding.

\section{Acknowledgements}

The authors are grateful to the Director, ICAR-CIFE, Mumbai for providing all the necessary facilities for this research.

\section{References}

Ahmad, I., Leya, T., Saharan, N., Asanaru Majeedkutty, B. R., Rathore, G., Gora, A. H., Bhat, I. A. and Verma, A. K. 2019. Carbon sources affect water quality and haemato $\square$ biochemical responses of Labeo rohita in zero $\square$ water exchange biofloc system. Aquac. Res., 50(10): 2879-2887. https://doi.org/10.1111/are.14241.

Ahmad, I., Verma, A. K., Babitha Rani, A. M., Rathore, G., Saharan, N. and Gora, A. H. 2016. Growth, non-specific immunity and disease resistance of Labeo rohita against Aeromonas hydrophila in biofloc systems using different carbon sources. Aquaculture, 457: 61-67. doi: 10.1016/j. aquaculture.2016.02.011

Avnimelech, Y. 1999. Carbon/nitrogen ratio as a control element in aquaculture systems. Aquaculture, 176: 227-235. https:// doi.org/10.1016/S0044-8486(99)00085-X.

Avnimelech, Y. 2007. Feeding with microbial flocs by tilapia in minimal discharge bioflocs technology ponds. Aquaculture, 264(1): 140-147. https://doiorg/10.1016/j. aquaculture.2006.11.025

Avnimelech, Y. 2012. Biofloc technology - A practical guide book. $2^{\text {nd }}$ edn. The World Aquaculture Society, Baton Rouge, USA, 272 pp.

Azim, M. E. and Little, D. C. 2008. The biofloc technology (BFT) in indoor tanks: Water quality, biofloc composition and growth and welfare of Nile tilapia (Oreochromis niloticus). Aquaculture, 283: 29-35. https://doi.org/10.1016/j. aquaculture.2008.06.036.

Bakar, N. S. A., Nasir, N. M., Lananan, F., Hamid, S. H. A., Lam, S. S. and Jusoh, A. 2015. Optimisation of C/N ratios for nutrient removal in aquaculture system culturing African catfish (Clarias gariepinus) utilising Bioflocs Technology. Int. Biodeterior. Biodegrad., 102: 100-106. https://doi.org/10.1016/j.ibiod.2015.04.001. 
Bakhshi, F., Najdegerami, E. H., Manaffar, R., Tokmechi, A., Farah, K. R. and Jalali, A. S. 2018. Growth performance, haematology, antioxidant status, immune response and histology of common carp (Cyprinus carpio L.) fed biofloc grown on different carbon sources. Aquac. Res., 49(1): 393-403. https://doi.org/10.1111/are.13469.

Bossier, P. and Ekasari, J. 2017. Biofloc technology application in aquaculture to support sustainable development goals. Microb. Biotechnol., 10(5): 1012-1016. https://doi.org/10.1111/1751-7915.12836.

Crab, R., Defoirdt, T., Bossier, P. and Vestraete, W. 2012. Biofloc technology in aquaculture: Beneficial effects and future challenges. Aquaculture, 356-357: 351-356. https://doi. org/10.1016/j.aquaculture.2012.04.046.

Daniel, N. and Nageswari, P. 2017. Exogenous probiotics on biofloc based aquaculture: A review. Curr. Agric. Res. J., 5(1): 88-107. http://dx.doi.org/10.12944/CARJ.5.1.11.

Dauda, A. B., Romano, N., Ebrahimi, M., Karim, M., Natrah, I., Kamarudin, M. S. and Ekasari, J. 2017. Different carbon sources affects biofloc volume, water quality and the survival and physiology of African catfish Clarias gariepinus fingerlings reared in an intensive biofloc technology system. Fish. Sci., 83(6): 1037-1048. https:// doi.org/10.1007/s12562-017-1144-7.

De Schryver, P., Crab, R., Defoirdt, T., Boon, N. and Verstraete, W. 2008. The basics of bio-flocs technology: The added value for Aquaculture. Aquaculture, 277(3-4): 125-137. https:// doi.org/10.1016/j.aquaculture.2008.02.019.

De Silva, S. S. and Phuong, N. T. 2011. Striped catfish farming in the Mekong Delta, Vietnam: A tumultuous path to a global success. Rev. Aquac., 3(2): 45-73. https://doi.org/10.1111/ j.1753-5131.2011.01046.x

Deng, M., Chen, J., Gou, J., Hou, J., Li, D. and He, X. 2018. The effect of different carbon sources on water quality, microbial community and structure of biofloc systems. Aquaculture, 482: 103-110. https://doi.org/10. 1016/j.aquaculture.2017.09.030.

Duncan, D. B. 1955. Multiple range and multiple F- tests. Biometrics, 11: 1-42. doi: 10.2307/3001478.

Ekasari, J., Zairin, M., Putri, D. U., Sari, N. P., Surawidjaja, E. H. and Bossier, P. 2015. Biofloc based reproductive performance of Nile tilapia Oreochromis niloticus L. broodstock. Aquac. Res., 46(2): 509-512. https://doi.org/ 10.1111/are.12185.

Ezhilarasi, V., Verma, A. K., Babitha Rani, A. M., Harikrishna, V., Chandrakant, M. H., Ahmad, I. and Nageswari, P. 2019. Effect of different carbon sources on growth, non-specific immunity and digestive enzyme activity of amur carp (Cyprinus rubrofuscus Lacepede 1803) fingerlings in biofloc based rearing system using inland saline groundwater. Indian J. Fish., 66(3): 87-94. doi:10. 21077/ijf.2019.66.3.86206-11.
FAO 2016. Cultured aquatic species information programme: Penaeus Monodon (Fabricius, 1798). Food and Agriculture Organisation of the United Nations, Rome, Italy. http:// www.fao.org/fishery/culturedspecies/Penaeusmonodon/en.

Hargreaves, J. A. 2006. Photosynthetic suspended growth systems in aquaculture. Aquac. Eng., 34: 344-363. https:// doi.org/10.1016/j.aquaeng.2005.08.009.

Haridas, H., Verma, A. K., Rathore, G., Prakash, C., Banerjee, P. B. and Babitha Rani, A. M. 2017. Enhanced growth and immuno-physiological response of Genetically Improved Farmed Tilapia in indoor biofloc units at different stocking densities. Aquac. Res., 48(8): 4346-4355. https:// doi.org/ 10.1111/are.13256.

Hollender, J., vander Krol, D., Kornberger, L., Gierden, E. and Dott, W. 2002. Effect of different carbon sources on the enhanced biological phosphorus removal in a sequencing batch reactor. World J. Microbiol. Biotechnol., 18(4): 359-364. https://doi.org/10.1016/j.fsi.2018.12.040.

Ju, Z. Y., Forster, I., Conquest, L. and Dominy, W. 2008 Enhanced growth effects on shrimp (Litopenaeus vannamei) from inclusion of whole shrimp floc or floc fractions to a formulated diet. Aquac. Nutr., 14(6): 533-543. doi: 10.1111/j.1365-2095.2007.00559.x.

Kamilya, D., Debbarma, M., Pal, P., Kheti, B., Sarkar, S. and Singh, S. T. 2017. Biofloc technology application in indoor culture of Labeo rohita (Hamilton, 1822) fingerlings: The effects on inorganic nitrogen control, growth and immunity. Chemosphere, 182: 8-14. https:// doi.org/10.1016/j.chemosphere.2017.05.021.

Long, L., Yang, J., Li. Y., Guan, C. and Wu, F. 2015. Effect of biofloc technology on growth, digestive enzyme activity, hematology and immune response of Genetically Improved Farmed Tilapia (Oreochromis niloticus). Aquaculture, 448: 135-141. Doi: 10.1016/j.aquaculture.2015.05.017.

Mahanand, S. S., Moulick, S. and Rao, P. S. 2013. Water quality and growth of rohu Labeo rohita, in a biofloc system. J. Appl. Aquac., 25(2): 121-131. https://doi.org/10.1080/1 0454438.2013.788898.

Meritha, W. W., Suprayudi, M. A. and Ekasari, J. 2018. The growth performance and resistance to salinity stress of striped catfish Pangasius sp. juvenile in biofloc system with different feeding rates. Indonesin J. Aquac.,17(2): 113-119. https://doi.org/10.19027/17.2.113-119(In Indonesian).

Najdegerami, E. H., Bakhshi, F. and Lakani, F. B. 2015. Effects of biofloc on growth performance, digestive enzyme activities and liver histology of common carp (Cyprinus carpio L.) fingerlings in zero-water exchange system. Fish Physiol. Biochem., 42(2): 457-465. http://orcid.org/ 0000-0001-9180-081X.

Oehmen, A., Yuan, Z., Blackall, L. L. and Keller, J. 2004. Short-term effects of carbon source on the competition of polyphosphate accumulating organisms and glycogen accumulating organisms. Water Sci. Technol., 50(10): 139-144. doi:10.2166/wst.2004.0629. 
Panigrahi, A., Sundaram, M., Saranya, C., Swain, S., Dash, R. R. and Dayal, J. S. 2019. Carbohydrate sources deferentially influence growth performances, microbial dynamics and immunomodulation in Pacific white shrimp (Litopenaeus vannamei) under biofloc system. Fish Shellfish Immunol., 86: 1207-1216. https://doi.org/10.1016/j.fsi.2018.12.040.

Phan, T. L., Tam, B. M., Thuy, N. T. T., Geoff, G. J., Brett, I. A., Hao, N. V., Phuong, N. T. and Silva, S. S. D. 2009. Current status of farming practices of striped catfish Pangasianodon hypophthalmus in the Mekong Delta, Vietnam. Aquaculture, 296: 227-236. https://doi.org/10. 1016/j.aquaculture.2009.08.017.

Rajkumar, M., Pandey, P. K., Aravind, R., Vennila, A., Bharti, V. and Purushothaman, C. S. 2016. Effect of different biofloc system on water quality, biofloc composition and growth performance in Litopenaeus vannamei (Boone, 1931). Aquac. Res., 47(11): 34323444. https://doi.org/10.1111/are.12792.

Samocha, T. M., Patnaik, S., Speed, M., Ali, A. M., Burger, J. M., Almeida, R. V., Ayub, Z., Harisanto, M., Horowitz, A. and Brock, D. L. 2007. Use of molasses as carbon source in limited discharge nursery and grow-out systems for Litopenaeus vannamei. Aquac. Eng., 36(2): 184-191. https://doi.org/10.1016/j.aquaeng.2006.10.004.

Singh, A. K. and Lakra, W. S. 2012. Culture of Pangasianodon hypophthalmus in India: Impacts and present scenario. Pakistan J. Biol. Sci., 15(1): 19-26. DOI:10.3923/pjbs.2012.
Soedibya, P. H. T., Listiowati, E., Pramono, T. B, Prayogo, N. A. and Harisam, R. T. 2018. Growth performance of catfish (Clarias gariepenus) cultured of high density with biofloc system. E3S Web of Conferences, 47: 02002. https://doi. org/10.1051/e3sconf/20184702002.

Wang, C., Pan, L., Zhang, K., Xu, W., Zhao, D. and Mei, L. 2015. Effects of different carbon sources addition on nutrition composition and extracellular enzymes activity of bioflocs and digestive enzymes activity and growth performance of Litopenaeus vannamei in zero-exchange culture tanks. Aquac. Res., 47: 4307-4318. https://doi.org/ 10.1111/are.12784.

Widanarni, D. W. and Puspita, F. 2012. Application of probiotic bacteria through artificial feed to improve the growth performance of the tiger prawn Penaeus monodon. J. Appl. Sci. Ed., 2(1): 19-29 (In Indonesian).

Zhao, D., Pan, L., Huang, F., Wang, C. and Xu, W. 2016. Effects of different carbon sources on bioactive compound production of biofloc, immune response, antioxidant level and growth performance of Litopenaeus vannamei in zero $\square$ water exchange culture tanks. J. World Aquac. Soc., 47(4): 566-576. https://doi.org/10.1111/are.12784.

Zhao, P., Huang, J., Wang, X. H., Song, X. L., Yang, C. H., Zhang, X. G. and Wang, G. C. 2012. The application of bioflocs technology in high-intensive, zero exchange farming systems of Marsupenaeus japonicus. Aquaculture, 354-355: 97-106. https://doi.org/10.1016/j. aquaculture. 2012.03.034. 